\title{
ANTI-BULLYING AWARENESS OF HIGH SCHOOL STUDENTS IN YOGYAKARTA CITY
}

\section{Dila Rahmawati*, Suwarjo, Heri Retnawati \\ *Correspondent Author}

Dila Rahmawati

Universitas Negeri Yogyakarta

Jalan Colombo Nomor 1, Sleman,

Yogyakarta

Indonesia

Email: dilarahma1@gmail.com

Suwarjo

Universitas Negeri Yogyakarta

Jalan Colombo Nomor 1, Sleman,

Yogyakarta

Indonesia

Email: suwarjo@uny.ac.id

Heri Retnawati

Universitas Negeri Yogyakarta

Jalan Colombo Nomor 1, Sleman,

Yogyakarta

Indonesia

Email: heri_retnawati@uny.ac.id

Page

64-72

\begin{abstract}
This study aims to determine the anti-bullying awareness of high school students in Yogyakarta City. This research is a phenomenological type of qualitative research. The data in this study were collected through interview instrument guidelines and observation guidelines. The subjects in this study were 25 students from six different schools in Yogyakarta City. The study used data analysis by Miles and Huberman. The results of the study show that anti-bullying awareness among high school students in Yogyakarta City is good. This is evidenced by: 1) well-known definitions of bullying, forms of bullying, and the impact of bullying, both victims and perpetrators; 2) broad insight based on the experience of being a victim of bullying, seeing bullying behavior directly or indirectly, and initiatives to help victims of bullying; 3) no desire to bully friends; 4) the ability to make friends by keeping feelings for each other and still upholding the prevailing norms. The results of the study can be used as a reference for guidance and counseling teachers or counselors to design guidance and counseling services about bullying to prevent bullying in high school students in Yogyakarta City.

Keywords: anti-bullying awareness, bullying, high school students
\end{abstract}

\section{INTRODUCTION}

Bullying was aggressive behaviour intended to hurt others (Smith, 2016). Bullying was currently a serious issue for the Indonesian government. The NGO Plan International and the International Center for Research on Women (ICRW) claimed that the percentage of bullying cases among children in Indonesia was $84 \%$. It was higher than the record of bullying cases in Asia which reached 70\% (www.liputan6.com, 15 /3/2015). The RI Ministry of Social Affairs surveyed in 2017 said that the $84 \%$ figure showed that children who experienced cases of bullying ranged in age from 12-17 years (news.detik.com, 21/7/2017). 


\title{
65 I PSIKOPEDAGOGIA
}

\author{
JURNAL BIMBINGAN DAN KONSELING
}

Vol.10, No.2, December 2021

One of the areas in Indonesia that were still coping with bullying cases was the city of Yogyakarta. Supported by a statement from Rukmantara as the director of UNICEF for the Java Island Representative, $21 \%$ of children aged 13-17 years in Yogyakarta experienced bullying (jogja.tribunnews.com, 12/2/2019). SEJIWA's 2008 found that $67.9 \%$ of high school students reported bullying behaviour by teachers to students or between students in three big cities, namely Jakarta, Surabaya, and Yogyakarta,. The percentage of violence at the high school level sequentially was in Jakarta (72.7\%), Surabaya (67.2\%) and Yogyakarta (63.8\%) (sejiwa.org, 2008).

Bullying among school children occurs by several factors, including:

1. Socialization and development (Gruber \& Fineran, 2016).

2. Psychological problems such as depression and anxiety are triggered by violence in the family and social environment (Benedict, Vivier, Gjelsvik, 2015).

3. Low self-control, unharmonious teacher-student relationships, inadequate parental supervision, and unhealthy relationships.

4. The application of discipline that is too strict and excessive parental aggressive behaviour in meeting the needs of children can easily include the students in bullying behaviour (Omoteso in Al-Raqqad, Al-Bourini \& Aranki, 2017). Hence, the trigger for bullying behaviour could come from within or outside the individual.

In general, there was verbal, physical, and emotional bullying (Efianingrum, 2009). However, this behaviour could reappear itself over time (Rigby, 2017). Gaffney, Farrington, and Ttofi (2019) explained that individuals who got bullied in childhood might re-do the behaviour as adults. There were various forms of bullying behaviour. Ranging from verbal bullying (such as calling improper names and giving threats), visual bullying (hitting, kicking, and damaging the victim's belongings), social aggression (such as spreading of incorrect numbers and ostracism) and mocking through social media, internet and technology were called cyber bullying (Monks \& Smith, 2006; Olweus, 1995;
Smith, 2014 in Menesini \& Salmivalli, 2017). Moreover, bullying had followed the development of the times where it was no longer carried out in the real (traditional) world but has penetrated the virtual world through several kinds of social media.

Bullying behaviour harmed the perpetrator and the victim. The perpetrator consequences were low interaction skills (Pratiwi, 2016). The perpetrator's behaviour caused the rising of depression and anxiety, ostracisation, misbehaviour, academic achievement declined, and anti-social personality disorder diagnosed (Sweater \& Hymel, 2015). Then, victims of bullying have social anxiety and a high level of depression (Zych, Ruiz, \& Rey, 2015).

Bullying behaviour could be prevented or reduced by involving individuals, parents, school personnel, media, non-governmental organizations, and security units (Turkmen et al., 2013). Therefore, bullying anticipation could be pursued by an educational process involving teachers. This educational process started from formal, informal, and non-formal activities (Zurqoni et al., 2018). Nowadays, education is a place for knowledge transfer and organizing the students to face modern era challenges such as bullying behaviour (Hadi, Retnawati, Munadi, Apino, and Wulandari, 2018). Veenstra et al. (2014) argued that teachers were agents who had a crucial role in anti-bullying programs. Therefore, they should be seen as intervention targets. The teachers could provide the widest opportunity for students to construct their knowledge about bullying awareness (Khomsiatun \& Retnawati, 2015). Hajdaraj (2017) described teachers' attitudes and cultures also influenced the school antibullying strategy. Based on the interviews with Guidance and Counseling teachers at SMAN 6 and SMAN 8 Yogyakarta, providing guidance services about the effect of bullying for the students can decrease the number of schools bullying. However, these efforts were not optimal because the teachers only did what they could.

The efforts of eliminating bullying behaviour took much time. Therefore, schools should hold annual interventions regularly 
(Fekkes, Pijpers \& Vanhorick, 2006). Antibullying interventions were usually effective to decrease bullying. Nonetheless, its success depended on the components of the implemented program (Zych, Ruiz, \& Rey, 2015). Furthermore, anti-bullying intervention successes depended on strong evidence and theory (Hall, 2017). Sometimes it is difficult to identify bullying behaviour among the students because the perpetrator usually said that his actions were unintentional or teased his friend (Swank, Adcock, \& Weaver, 2019). This statement was one example of a person who lacked awareness of bullying, so he thought bullying was normal. Therefore, the students needed anti-bullying awareness to recognize bullying action. In addition, increasing awareness of anti-bullying was required to understand the meaning and consequences of bullying and anticipate the students being the perpetrator (Linasari, 2016).

The school intervention program was significant evidence of bullying prevention awareness (Fekkes, Pijpers \& Vanhorick, 2006). So, the students were aware of their role to oppose school bullying and improve anti-bullying norms and responses in the classroom (Menesini \& Salmivalli, 2017).

Furthermore, anti-bullying awareness could also improve students' social skills by building interpersonal relationships between peers(Swearer \& Hymel, 2015). Anti-bullying awareness could be one way to reduce the number of bullying cases. It can be started by constructing a positive social culture among students. However, to lead an intervention raising of anti-bullying awareness, the first step was finding out how anti-bullying awareness for high school students in Yogyakarta. This identification was expected to be the basis for formulating appropriate interventions for constructing anti-bullying awareness. Furthermore, the results of this study could be used as references for guidance and counselling teachers or counsellors in designing guidance and counselling services about bullying, especially for preventing school bullying in Yogyakarta.

\section{RESEARCH METHOD}

This study was a phenomenological type of qualitative research. Furthermore, the data were collected using interview techniques. The research subjects were 25 high school students in Yogyakarta. First, a purposive sampling technique was used to gather the research subject. Then, the interviews data were analyzed by qualitative data analysis using the Miles and Huberman analysis technique. Data analysis was carried out in three stages: reducing, presenting, and drawing conclusions or verification.

\section{RESULT AND DISCUSSIONS}

The researcher processed the data transcriptions. Then, the interview transcript was reduced to the sub-themes. Furthermore, the interview data description between subthemes was associated in formulating the conclusions. In this study, four themes were used to detect anti-bullying awareness levels among high school students in Yogyakarta. The themes are:

1. Bullying behaviour understanding.

2. Bullying experiences and reactions

3. Bullying desire.

4. Bullying experience.

The first theme was bullying behaviour understanding. Bullying was one of the spotlights in Yogyakarta that should be overcome and prevented through various parties cooperation. Therefore, it was important to know students' knowledge about bullying behaviour to eliminate bullying. If students had broad experience and understanding of bullying, the prevention might be easier. The description of each interview sub-theme, which discussed bullying behaviour understanding, was presented in table 1 below:

Tabel 1

\begin{tabular}{|c|c|c|}
\hline No. & Sub-theme & $\begin{array}{l}\text { Relationship } \\
\text { between sub- } \\
\text { themes }\end{array}$ \\
\hline & $\begin{array}{l}\text { Bullying was excessive } \\
\text { joking or behaviour. }\end{array}$ & $\begin{array}{l}\text { Most students } \\
\text { were }\end{array}$ \\
\hline 2. & $\begin{array}{l}\text { Bullying could cause } \\
\text { mentally damaging. }\end{array}$ & $\begin{array}{l}\text { unknowledgeable } \\
\text { about the }\end{array}$ \\
\hline 3. & $\begin{array}{l}\text { Bullying was behaviour in } \\
\text { the form of words or physical } \\
\text { violence. }\end{array}$ & $\begin{array}{l}\text { definition of } \\
\text { bullying in detail. }\end{array}$ \\
\hline
\end{tabular}




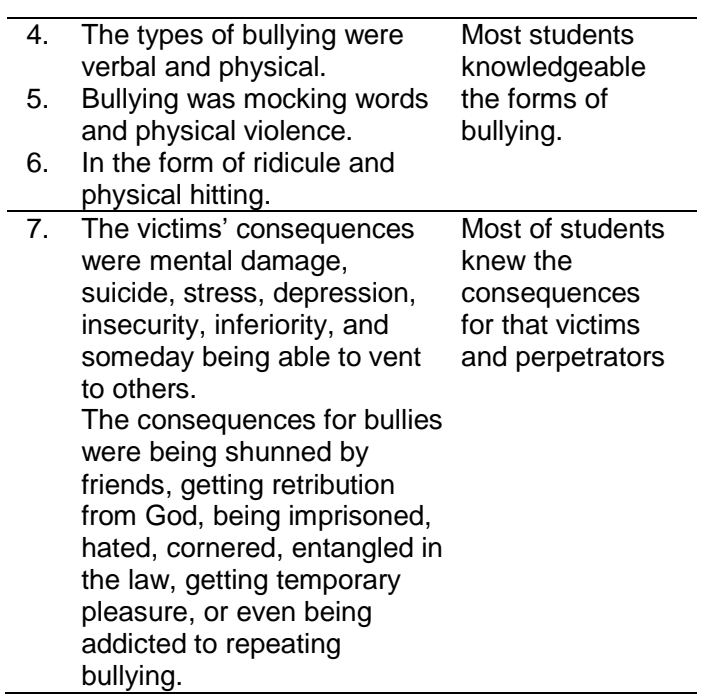

Based on the interviews, some students considered bullying excessive behaviour or joking, and others interpreted bullying as words or physical violence that could damage mentally. Therefore, the form of bullying could be verbal or physical. Hence, students consider bullying as a behaviour that could harm victims, either by touching it directly or through speech intermediaries. Unfortunately, students did not understand what was categorized as bullying. Therefore, this indepth understanding needed to be possessed so that it was not easy for people to call it a form of bullying.

Something could be said as bullying if the students did some actions intensively and repeatedly, and the victim's power was an imbalance with the perpetrator's strength. Detailed understanding could at least minimize misunderstandings about how to joke with high school students who generally still used ridicule or physical touch as a way to joke with their friends. Some examples of student statements that supported the theme of understanding bullying behaviour were:

"Yes, bullying is behaviour that makes others mentally damaged" (Student 1 )

"Bullying is an excessive action, you know, it can be physical, or it can come from speech too." (Student 2)

"In my opinion, bullying is like making fun of a friend, but it is already getting worse. It's too much." (Student 3)

In addition to understanding bullying, students also conveyed the possible consequences that the perpetrators and victims of bullying could accept. For example, students felt that the impact of bullying could threaten mental health and lead to suicide. The students understood the impact on victims from various reports that had been widely circulated in the community. Some students also felt that the effect that has emerged was very dangerous, including one of them was that victims could turn into perpetrators in the future if they did not get proper treatment.

However, the perpetrator could get the consequences of the bullying. Students assumed that perpetrators could get social sanctions from society and friendship in the form of being cornered, hated, and shunned by the people around them. Students also believed that the law would act fairly by ensnaring the perpetrators according to the applicable laws and regulations. Even some students believed that there would be a reply from God. Conversely, students still thought that the more often the perpetrators bullied and felt proud of what they had done, the more likely they would become addicted to bullying. Thus, students' understanding of bullying behaviour was still limited to what had been heard and seen. On the other hand, students had a fairly broad knowledge of the forms and consequences of bullying, both from the victim and the perpetrator.

The second theme was the students' experiences and reactions to bullying. Each individual would have a different experience related to bullying behaviour by others. Bullying could place the individual as a witness or victim. Through this experience, individuals had their views and knowledge regarding bullying they used as learning in the future. The following table 2 showed the results of interviews about the experiences and reactions of high school students to bullying by others:: 
Tabel 2

Reaction to Bullying

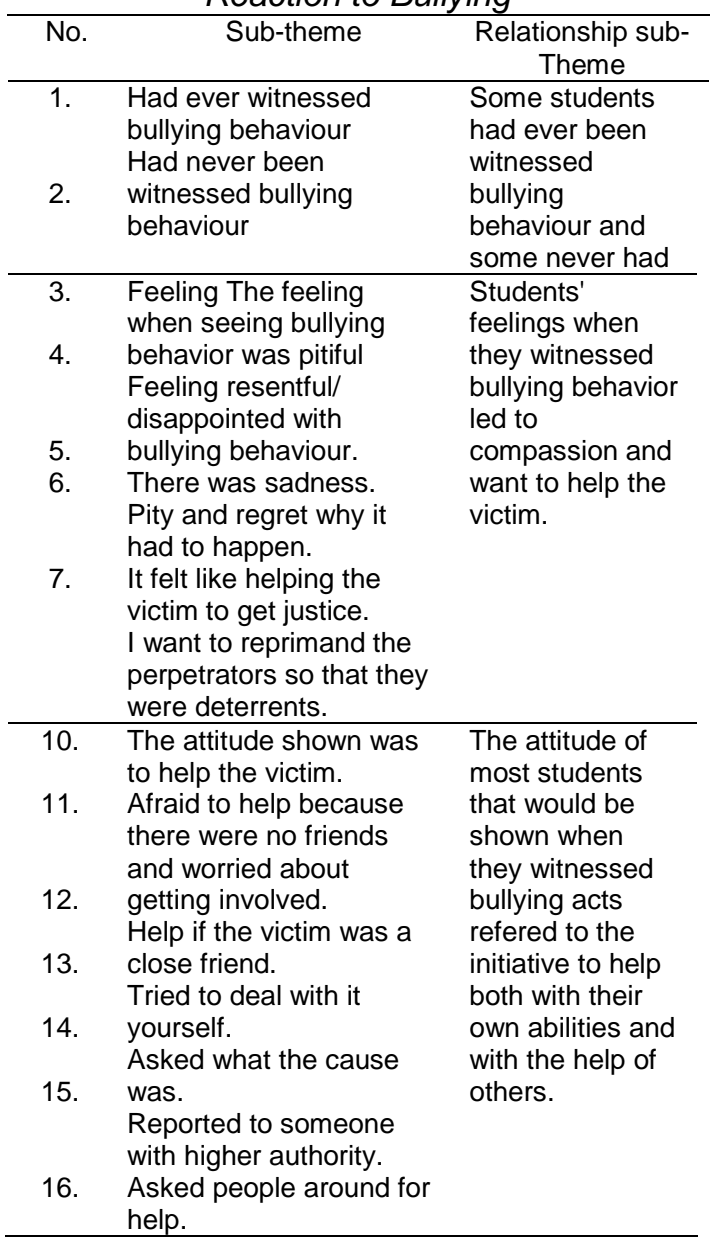

This experience was also felt by some high school students in Yogyakarta who claimed eyewitnesses of bullying. The acts of bullying were carried out by various parties, such as family members, close friends, or fellow students at school. Then, some other students who had never seen it in person admitted that they only witnessed bullying acts spread on social media or online news portals. Apart from being witnesses, several students claimed to have been victims of bullying by their friends at school. The reason for this tended to be the social jealousy of the victim.

This phenomenon certainly raised various reactions from students. The multiple responses included feeling sad because some of the perpetrators of bullying were underage, annoyed/upset by the bullying that was carried out, sad because it turned out that bullying had penetrated social media, sorry for the physical or mental condition of the victim, and regretting arbitrary actions for what the perpetrator did. Behind these feelings, some students desired to help victims and even reprimanded the perpetrators when they saw bullying happening in front of their eyes. Students said it needed to be done to give justice to the victims and perpetrators

When asked about the attitude shown when they saw bullying, students gave different answers according to their respective reasons. Some students answered that they would help the victim as much as possible, but some were afraid to help because there were no friends and worried they would be involved in the problem. Students prefer to help the victim if he was a close friend. Another way students chose to overcome it was by asking what the cause was. Some students believed that involving other people would only make things worse. This view did not generally apply because several students ask for help from people around them to break up bullying. In addition to breaking up, students admitted that they dared to report bullying to others who had higher authority.

Thus, all students did not experience seeing bullying behaviour directly. However, most students showed compassion when they learned about the victims of bullying and were moved to help in their way. The following were some student statements that reinforced the theme of experiences and reactions to bullying by others:

"I am not a witness. I am a victim of ridicule by my friends at school just because my motorbike is different from theirs." (student 24)

"It is really sad to know that the ones who do the bullying are small children. What do they not think? That is stupid." (student 16)

"Yes, you have to help, especially if it is your friend. I dared to come forward to defend it." (students 10)

The third was the desire to do the bullying. The willingness to bully was one of the themes highlighted in this study. Table 3 revealed an explanation regarding the willingness to do bullying: 
Table 3

Intention to Bully

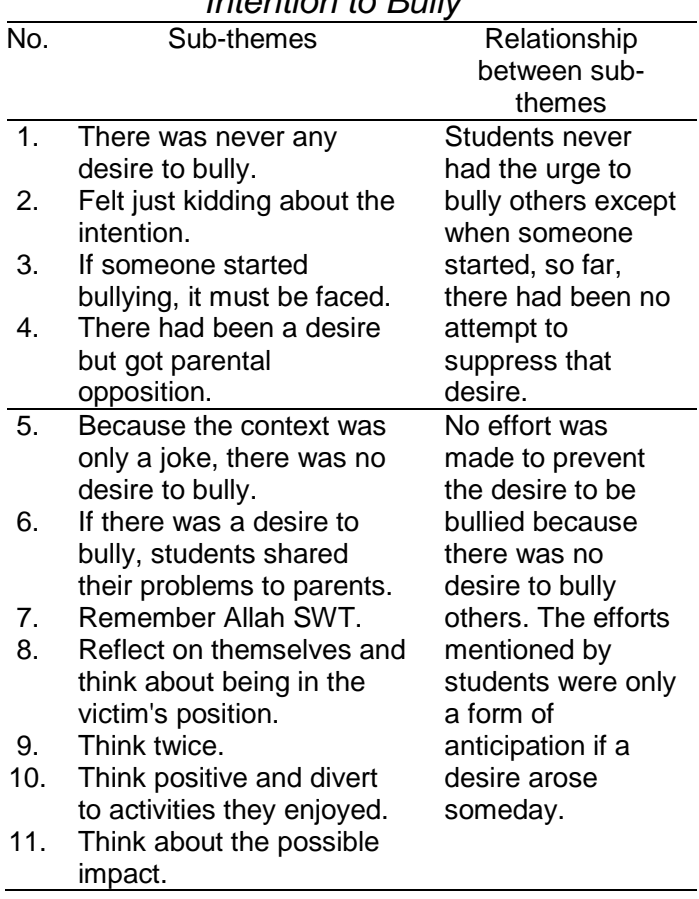

Desire was an impulse that arose from within a person to take action. Furthermore, the desire to bully was an impulse in the individual to bully others. This theme described the extent to which students were willing to do bully. However, based on the interviews, almost all students admitted that they never wanted to bully others. The students reasoned that so far, what they did was still in the stage of a good joke.

The way students joke was generally used as ridicule to get to know each other. Some even say that someone could not be friends if he took the joke too seriously. However, if someone else started to bully first one day, students would not hesitate to face it either with their strength or with the help of others.

In contrast to other students' answers, students who experienced bullying said they had a strong desire to bully others. They vented as revenge for the bullying they had survived before. They explained their willingness to parents, but in the end, they could do because of parental opposition.

The desire to bully could happen to anyone, anytime, anywhere, and with anyone's target. Therefore, there was a need to prevent bullying from being controlled. The students described some methods to prevent the desire to do bullying. First, they shared about everyday stuff with parents so they would not make any bad decision. Second, they always remember that God sees us. Third, they had self-reflection to think about the victims' that suffered from bullying. Fourth, they thought about the impact that might arise after bullying for them. Finally, they thought positively, and drove their mind to do activities they enjoyed.

The absence of the desire to bully most students indicated that the city of Yogyakarta has begun to improve to minimize the number of bullying at the high school student level. The following were excerpts from student statements that supported this theme:

"Yes, I once had the desire to retaliate by turning around to bully my friends because I was so irritated. However, in the end, it did not happen. It could not be papa mama. (student 15)

"We are of school age, yes, it is natural to want to make jokes using mockery, but it is still within reasonable limits here." (student 8)

"Even if one day there is a desire to be bullied, please remember God a lot. Already." (student 6)

Fourth is the experience of doing the bullying. Concerning the desire to bully, the next thing that becomes the centre of attention is students' experience in bullying. The action referred to here is not limited to the school environment but extends to relationships, families, and communities. Table 4 below describes the reduction results related to students' experiences of bullying others: $t$, incidents of bullying. Concerning the desire to bully, the next thing that becomes the centre of attention is students' experience in bullying. Again, the action referred to here is not limited to the school environment but extends to relationships, families, and communities. Table 4 below presents a description of the results of the reduction related to students' experiences in bullying others: 
Tabel 4

Experience of Being The Bully

\begin{tabular}{lll}
\hline No. & \multicolumn{1}{c}{ Sub-theme } & $\begin{array}{c}\text { Relationship between } \\
\text { sub-theme }\end{array}$ \\
\hline 1. & $\begin{array}{l}\text { Some students } \\
\text { admitted that they had } \\
\text { never been the } \\
\text { perpetrators or victims } \\
\text { of bullying. }\end{array}$ & $\begin{array}{l}\text { Most of the students } \\
\text { had never done } \\
\text { bullying because they } \\
\text { think that the jokes } \\
\text { that had been done } \\
\text { so far were still within } \\
\text { normal limits, while a }\end{array}$ \\
$\begin{array}{ll}\text { Some students claimed } \\
\text { to have been victims of } \\
\text { bullying. }\end{array}$ & $\begin{array}{l}\text { small number of } \\
\text { students had felt like } \\
\text { The students admitted } \\
\text { that they had never } \\
\text { done bullying because victims of } \\
\text { they thought that the } \\
\text { jokes done so far were } \\
\text { still within normal limits. }\end{array}$ & $\begin{array}{l}\text { bullying. } \\
\text { 4ktivitas saling The }\end{array}$ \\
$\begin{array}{l}\text { mocking activities } \\
\text { carried out so far were } \\
\text { considered joking so } \\
\text { that students felt happy, } \\
\text { fun, and it was } \\
\text { acceptable }\end{array}$ & $\begin{array}{l}\text { All students } \\
\text { emphasized that they } \\
\text { were only joking so } \\
\text { that the feelings that } \\
\text { emerged after joking } \\
\text { with friends were } \\
\text { happy and felt } \\
\text { exciting. }\end{array}$ \\
\hline
\end{tabular}

Fourth is the experience of doing the bullying. Concerning the desire to bully, the next thing that becomes the centre of attention is students' experience in bullying. The action referred to here is not limited to the school environment but extends to relationships, families, and communities. Table 4 below described the reduction results related to students' experiences of bullying others: bullying incidents. Concerning the desire to bully, the next thing that becomes the centre of attention is students' experience in bullying. The action referred to here is not limited to the school environment but extends to relationships, families, and communities. Table 4 below describes the reduction results related to students' experience in doing. Looking back that the background of high school students is teenagers with an age range between 15-18 years, then the way of joking done by mocking is assumed to get close friends. Students label that a fun friendship is a friendship that is not rigid and believed that friends who are difficult to joke with are not part of the friendship. Students admitted that the jokes carried out were still within reasonable limits. If people are ridiculed in general, they will become angry, but this is not the case for students. This is marked by an attempt to change the topic of conversation when they feel that the friend being the target is no longer comfortable. There was never excessive joking that involved physical and verbal arguments. Most of the students involved in the interviews admitted that their jokes caused feelings of pleasure, fun, and even normalcy in students. Some student statements that support this description include: bullying others:

"It is just relaxing, how come it is not bullying, it is just a joke. If you do not like it, do not join our circle of friends." (student 9)

"Sometimes those who are ridiculed also laugh. He does not hurt because he knows this is just a joke." (student 20)

"If you do not joke like this, your friendship will be stiff, if you use jokes, even if you make fun of it a little, it is fun." (students 11)

Regarding the perpetrators and victims, some students claimed to have been victims of bullying by friends at school, and others said they had never been victims or perpetrators. The underlying reason was the condition of the school environment. Schools with economic conditions that were not too unequal did not lead to bullying behaviour. In contrast, schools with unequal economic and social conditions allowed students to bring down friends who were not on the same level as them.

The descriptions of the student's answers showed how deep students' understanding of bullying was still rife. Students' strong knowledge of bullying acts as one of the hopes that anti-bullying awareness could be increased quickly. On the other hand, it was still necessary to make greater efforts to increase anti-bullying awareness in students who had limited understanding. In this study, it was found that most students had a limited knowledge of the definition of bullying. However, the positive thing that could be appreciated was a fairly broad understanding of the forms and consequences of bullying. For example, students mentioned that bullying could be ridicule and physical words such as hitting. The results of this study followed the results of Octavianto's research (2017). Students also mentioned various consequences that victims and perpetrators of bullying could receive. An example of a 


\section{1| PSIKOPEDAGOGIA}

JURNAL BIMBINGAN DAN KONSELING

Vol.10, No.2, December 2021

consequence for a victim that requires special preventive treatment so that it does not happen in the future was the possibility of the victim being a perpetrator of bullying for others. This could happen because of the assumption that bullying was normal in everyday life. This finding followed Levianti's (2008) research results.

The students' experiences witnessing bullying could be an insight into bullying behaviour. The students might witness bullying by family, playmates, or fellow students at school. As supported by Zakiyah, Humaedi, and Santoso (2017). However, all students had this experience. The development of technology has made it easier for individuals to access the widest possible information related to bullying. Accessing social media and online news portals allowed students who did not have bullying experience to understand the effects that caused various reactions from feelings and actions. Students said they also feel sad, regretful, annoyed, and mixed other emotional responses that show disapproval of bullying. The emotions that arose based on humanity eventually led to a desire in students to help victims. According to the students' explanation, it was indirectly illustrated that all participants were against bullying. These results were from previous research conducted by Arsela, Pohan, \& Djuwita (2013).

\section{CONCLUSION}

Referring to the analysis that had been done, high school students in Yogyakarta were already open to the problem of bullying. Students understood the definition and form of bullying and conveyed the consequences for victims and perpetrators. Students had realized that bullying was not a justified action, so in joking with friends, they still paid attention to boundaries so as not to cause verbal or physical disputes.

Moreover, high school students in Yogyakarta already had a pretty good antibullying awareness. These results can be used as a basis for reference in further research related to counseling guidance teachers in the city of Yogyakarta to increase anti-bullying awareness of high school students. In addition, this study can be used as a reference to expanding the reach of research at other levels of education. Further handling is needed for students who are victims of bullying to raise their confidence in front of others. An annual routine service program on bullying prevention is made that is packaged with interesting techniques so that students easily understand it.

\section{REFERENCES}

Al-Raqqad, H. K., Al-Bourini, E. S., \& Aranki, R. M. E. (2017). The Impact of School Bullying on Students' Academic Achievement from Teachers Point of View. International Education Studies, 10(6), 44-50.

Arsela, D., Pohan, L. D., \& Djuwita, R. (2013). Adolescent Attitude Toward Bullying in Urban High School. Skripsi.

Benedict, F. T., Vivier, P. M., \& Gjelsvik, A. (2015). Mental Health and Bullying in The United States Among Children Aged 6 to 17 Years. Journal of Interpersonal Violence, 30(5), 782795.

Darmawan. (2017). Fenomena Bullying (Perisakan) di Lingkungan Sekolah. Jurnal Kependidikan, 1(1), 253-262.

Efianingrum, A. (2009). Mengurai Akar Kekerasan (Bullying) di Sekolah. Jurnal Dinamika.

Fekkes, M., Pijpers, F. I. M., \& Vanhorick, S. P. V. (2006). Effects of Antibullying School Program on Bullying and Health Complaints. ARCH Pediatr Adolesc Med, 160(6), 638-644.

Gaffney, H., Farrington, D. P., \& Ttofi, M. M. (2019). Examining the Effectiveness of School-Bullying Intervention Programs Globally: a Meta-Analysis. International Journal of Bullying Prevention, 1, 1431.

Gruber, J., \& Fineran, S. (2016). Sexual Harassment, Bullying, and School Outcomes for High School Girls and Boys. Violence Against Women, 22(1), 112-133.

Hadi, S., Retnawati, H., Munadi, S., Apino, E., \& Wulandari, N. F. (2018). The Difficulties of High School Students in Solving Higher-Order Thinking Skills Problems. Problems of Educationin The 21st Century, 76(4), 520-531.

Hajdaraj, Y. (2017).Teachers' Knowledge of Bullying and Their Anti-Bullying 
Attitude. European Journal of Social Sciences Studies, 2(2), 1-11.

Hall, W. (2017). The Effectiveness of Policy Interventions for School Bullying: a Systematic Review. J Soc Social Work Res, 8(1), 45-69.

Jogja.tribunnews.com. (22 Juli 2017). 117 Laporan Bullying Diterima Tepsa Kemensos RI Hingga Juli 2017. Diakses pada 19 Desember 2019, dari http://jogja.tribunnews.com/2017/07/22 /117- laporan-bullying-diterimatepsa-kemensos-ri-hingga-juli-2017

Khomsiatun, S., \& Retnawati, H. (2015). Pengembangan Perangkat Pembelajaran dengan Penemuan Terbimbing untuk Meningkatkan Kemampuan Pemecahan Masalah. Jurnal Riset Pendidikan Matematika, 2 (1), 91-106.

Kurniawan, Y., \& Sudrajat, A. (2018). Peran Teman Sebaya dalam Pembentukan Karakter Siswa Madrasah Tsanawiyah. Socia Jurnal IImu-IImu Sosial, 15(2), 149-163.

Levianti. (2008). Konformitas dan Bullying pada Siswa. Jurnal Psikologi, 6(1), 1-9.

Linasari, T. (2016). Keefektifan Videotherapy dalam Menumbuhkan Kesadaran AntiBullying pada Siswa Kelas V. Jurnal Pendidikan Guru Sekolah Dasar, 36(5), 3438-3448.

Liputan6.com. (15 maret 2015). Survei ICRW: 84\% Anak Indonesia Alami Kekerasan di Sekolah. Diakses pada 19 Desember 2019, dari https://www.liputan6.com/news/read/2 191106/survei-icrw-84-anak-indonesia -alami-kekerasan-di-sekolah

Menesini, E., \& Salmivalli, C. (2017). Bullying in Schools: The State Of Knowledge and Effective Interventions. Psychology, Health \& Medicine, 22(1), 240-253.

Moon, B., \& Alarid, L. F. (2015). School Bullying, Low Self-Control, and Opportunity. Journal of Interpersonal Violence, 30(5), 839-856.

Octavianto, M. R. (2017). Perilaku Bullying di Sekolah Menengah Atas Kota Yogyakarta. Jurnal Riset Mahasiswa Bimbingan dan Konseling, 3(8), 376385.

Pratiwi, R. P. (2016). Hubungan Perilaku Bullying dengan Kemampuan Interaksi Sosial Siswa Kelas III SDN Minomartani 6 Sleman. Jurnal
Pendidikan Guru Sekolah Dasar, 2(5), 141-151.

Rigby, K. (2017). School Perspectives on Bullying and Preventative Strategies: an Exploratory Study. Australian Journal of Education, 61(1), 24-39.

Sejiwa. (2008). Penelitian. http://sejiwa.org/bullying-researches/

Smith, P. K. (2016). Bullying: Definition, Types, Causes, Consequences and Intervention: Bullying. Social and Personality Psychology Compass, 10(9), 519-532.

Swank, J. M., Adcock, S. S., \& Weaver, J. L. (2019). School Counselors' Roles and Responsibilities in Bullying Prevention: a National Survey. Professional School Counseling, 22(1), 1-11.

Swearer, S. M., \& Hymel, S. (2015). Understanding the Psychology Of Bullying Moving Toward a SocialEcological Diathesis-Stress Model. American Psychologist, 70(4), 344353.

Turkmen, N., et al. (2013). Bullying Among High School Students. MAEDICA - a Journal of Clinical Medicine, 8(2), 143152.

Veenstra, R., at all. (2014). The Role of Teachers in Bullying: The Relation between Antibullying Attitudes, Efficacy, And Efforts To Reduce Bullying. Journal of Educational Psychology, 106(4), 1135-1143.

Zakiyah, E. Z., Humaedi, S., \& Santoso, M. B. (2017). Faktor yang Mempengaruhi Remaja dalam Melakukan Bullying. Jurnal Penelitian \& PPM, 4(2), 129-389.

Zurqoni, dkk. (2018). Strategy and Implementation of Character Education in Senior High Schools and Vocational High Schools. Journal of Social Studies Education Research, 9(3), 379-397.

Zych, I., Ruiz, R. O., \& Rey, R. D. (2015). Systematic Review of Theoretical Studies on Bullying and Cyberbullying: Facts, Knowledge, Prevention, and Intervention. Aggression and Violent Behavior, 23, 1-21. 